Fikrah: Jurnal Ilmu Aqidah dan Studi Keagamaan

issn 2354-6147 eissn 2476-9649

Tersedia online di: journal.stainkudus.ac.id/index.php/Fikrah

DOI: https://doi.org/10.21043/fikrah.v4i1.1612

Artikel diserahkan : 31 Agustus 2016; Diterima: 4 Oktober 2016

\title{
Agama; Antara Cita dan Kritik
}

\author{
MK Ridwan \\ Institut Agama Islam Negeri (IAIN) Salatiga, Indonesia \\ mkridwan13@gmail.com
}

Adang Kuswaya

Institut Agama Islam Negeri (IAIN) Salatiga, Indonesia

dangkuswaya@gmail.com

\section{Muhammad Misbah}

STAIN Kudus, Indonesia

misbah@stainkudus.ac.id

\begin{abstract}
Abstrak
Fenomena keagamaan berada dalam permasalahan kompleks. Agama dalam realitas kemanusiaan seakan memiliki wajah mendua. Pada satu sisi, agama dihadapkan dengan permasalahan konflik antar umat beragama. Agama mempertontonkan arogansi berupa kekerasan, peperangan, kebencian bahkan pembunuhan. Namun di sisi lain, agama dihadapkan pada realitas ketidakberdayaan. Betapa umat beragama masih mengalami kemiskinan, pemiskinan, ketidakadilan, kebodohan, keterbelakangan dan penindasan. Ini menunjukkan bahwa agama belum mampu mengatasi problem sosial. Melalui tulisan ini, kompleksitas dan keruwetan wajah agama, berusaha untuk dibedah menggunakan pisau analisis sosiologis-hermeneutis yang menekankan pada proses dialektika antara idealitas dengan realitas masyarakat beragama. Sehingga menghasilkan sebuah kesimpulan bahwa masyarakat beragama harus mampu dan mau menerapkan prinsip gerak menuju agama cita. Yaitu sebuah paradigma futuristik yang berangkat dari
\end{abstract}


pemahaman agama secara optimis-positivistik. Sebagai langkah gerakan konseptual-praksis-fungsional agama sebagai katalisator perubahan sosial. Maka, akan ditemukan sebuah peran agama yang lebih responsif dan kooperatif dalam regulasi sosial, tatanan moral, transformasi sosial, serta menciptakan dan mengatur bentuk-bentuk sosial-kebudayaan.

Kata Kunci: Agama, konflik, nilai-nilai universal, kooperatif, perubahan sosial

\begin{abstract}
The religious phenomena are complex issues. Religion in human reality seemed to have an ambiguous face. Religion is faced by the problem of inter-religious conflict. Religion displays the arrogance of violence, war, hatred and even murder. On the other hand, religion is faced by the reality of helplessness. Religious communities are experiencing poverty, deprivation, injustice, ignorance, backwardness and oppression. It shows that religion has not been able to solve social problems. The complexity and intricacy of religious face are trying to be analyzed by the hermeneutical sociological analysis emphasizing the dialectical process between ideals with the reality of religious communities. The result showed that religious communities should be able to apply the principle of motion towards religious ideals. That is a futuristic paradigm which departs from religious understanding optimistically-positivistic. As a practical movement step of functional conceptual religion as a catalyst for social change. Thus, the role of religion will be found a more responsive and cooperative in the regulation of social, moral order, social transformation, as well as creation and organization of sociocultural forms.
\end{abstract}

Keywords: Religion, conflict, universal values, cooperative, social change

\title{
Pendahuluan
}

Berbicara tentang agama memerlukan suatu sikap ekstra hati-hati. Agama merupakan persoalan sosial, tetapi penghayatannya sangat bersifat individual. Apa yang dipahami dan dihayati sebagai agama oleh seseorang sangat bergantung pada keseluruhan latar belakang dari kepribadian dan memunculkan sikap menuntut adanya pembenaran langsung. Semua orang memang telah mengetahui bahwa terdapat kepekaan yang sangat tajam pada masalah-masalah yang berhubungan dengan agama. Kini persoalan agama memang telah menjadi permasalahan umat manusia sepanjang masa. Agama menjadi entitas terdalam kemanusiaan yang melandasi setiap aktivitas kehidupannya. Agama senantiasa menempati ruangruang kehidupan manusia. Maka, sejarah agama dapat dikatakan sebagai sejarah kemanusiaan.

Karena agama menjadi cara pandang (weltanschauung) manusia terhadap 
kehidupan dan alam semesta. Agama mengandung ajaran tentang hubungan manusia dengan masyarakat, alam semesta dan Tuhan. Sehingga memungkinkan terjadinya perbedaan dalam pandangan dunia seorang Muslim dengan Kristiani, Budha dengan Hindu, Yahudi dengan Konghucu, dan seterusnya (Jauhari, 2012, hal. 144). Agama (baca: iman) sebagai pandangan dunia (weltanschauung) selanjutnya mempengaruhi kepercayaan, tata nilai, sikap, aspek kebudayaan, yang tercermin dalam bentuk kerja kemanusiaan (amal saleh). Manusia akan dengan antusias bertindak ketika ia memiliki kualitas keyakinan yang mendalam. Keyakinan akan memberikan inspirasi gerak pada seseorang untuk berbuat dan berkorban demi mempertahankan kebenarannya (Sudarto, 2014, hal. 114).

Sebuah kenyataan bahwa masyarakat Indonesia dikenal sebagai masyarakat plural. Beragam etnis, suku-bangsa, dan agama tumbuh subur di Indonesia dengan berbagai latar kebudayaan dan pandangannya masing-masing. Potensi ini selain bersifat positif-konstruktif karena memperkaya khazanah kebudayaan Indonesia, tetapi juga dapat berdampak negatif-destruktif jika tidak diatur dengan baik. Potensi terjadinya konflik dengan latar perbedaan etnis, suku-bangsa, dan yang terparah adalah konflik atas nama agama dapat menyebabkan disintegrasi bangsa (Mulkhan, 2012, hal. 74).

Kesadaran akan kompleksitas dan bahaya konflik antar umat beragama, semakin meningkat sejak peristiwa 11 September 2001. Namun, pengetahuan tentang penyebab dan rumusan solusinya hingga saat ini masih terbilang minim (Kimbal, 2008, hal. 199). Meskipun berbagai wacana tentang toleransi umat beragama telah banyak didiskusikan di berbagai forum-forum ilmiah mengenai berbagai kajian harmoni kehidupan beragama. Realitas yang terjadi di masyarakat justru masih banyak terjadi konflik yang bertendensi atas nama agama. Kenyataan ini menunjukkan bahwa upaya harmonisasi antar umat beragama masih belum bisa dikatakan berhasil. Walaupun berbagai tawaran metodologis dan praksis telah banyak dihasilkan oleh berbagai kalangan akademisi maupun pemuka agama (Wasim dkk, 2005).

Sementara masyarakat beragama disibukkan dengan berbagai macam konflik dan radikalisme, wajah agama juga dihadapkan pada tantangan modernitas dengan berbagai tuntutan kehidupan umat manusia. Agama dihadapkan pada realitas empirik yang menyedihkan; kemiskinan, ketertindasan, kebodohan, korupsi, imperialisme budaya, dan berbagai problematika lainnya yang menegaskan bahwa agama belum bisa mengatasi persoalan yang dihadapi masyarakat saat ini (Prasetyo, 2002, hal. v). Agama dan realitas kemanusiaan bagaikan dua entitas yang berbeda, karena agama berada di sebuah sudut, sedangkan problem kemanusiaan di sudut yang lain. Agama akan semakin kehilangan fungsinya ketika tidak mampu memberikan jalan keluar bagi kemelut dan krisis umat manusia. Di sinilah, kompleksitas agama hari ini dengan berbagai tantangannya. Seolah agama memiliki wajah mendua, sebagaimana dikemukakan R. Scott Appleby (2000), bahwa agama mengandung ambiguitas, di mana agama pada satu sisi menghasilkan nilai-nilai humanistis dan spirit pembebasan. Namun di sisi lain, agama memperlihatkan arogansi dan otoritarianisme yang membelenggu dan membebani penganutnya.

Perandanfungsiagamadalam pentasduniaglobal,kembaliperludipertanyakan. 
Apakah agama bisa menjadi alternatif penyembuhan bagi manusia dari cengkeraman kemiskinan, penindasan, pengangguran, ketidakadilan, kekerasan, dan konflik? Atau justru agama mejadi bagian pemicu persoalan daripada menyelesaikan berbagai permasalahan. Dengan menggunakan pendekatan sosiologis-hermeneutis, tulisan ini berusaha untuk mengeksplorasi secara deskriptif-analitis dalam membedah keruwetan wajah agama hari ini. Agama sebagai dimensi terdalam kemanusiaan perlu ditafsir ulang menggunakan perspektif baru untuk menghasilkan pemahaman segar yang membebaskan.

\section{Konsepsi Beragama; Sebuah Idealitas}

Berdasarkan sudut pandang kebahasaan, agama dapat dipahami dari berbagai sisi. Secara etimologis, kata agama "religie" (bahasa Belanda) dan "religion" (bahasa Inggris) keduanya memiliki akar kata religare (bahasa Latin). Religare memiliki arti melakukan suatu perbuatan dengan penuh penderitaan, yakni sejenis perilaku atau praktik peribadatan yang dikerjakan secara berulang-ulang dan bersifat mengikat (Ismail, 2014, hal. 5). Sedangkan dalam bahasa Arab, agama berasal kata al-diin yang berarti menundukkan, kepatuhan, utang, agama, dan balasan (Ibn Manzur, 1979, hal. 1437). Maka, agama pada dasarnya membawa sejumlah peraturanperaturan berbentuk hukum (norma) yang harus dilaksanakan oleh penganutnya sebagai sikap tunduk dan patuh kepada Tuhan. Sehingga, bagi yang melaksanakan hukum Tuhan akan mendapatkan balasan yang baik, begitupun yang mengingkari akan mendapatkan balasan yang buruk. Definisi ini mengacu kepada ekspresi suatu bentuk ketergantungan pada kekuatan di luar diri manusia, yakni kekuatan spiritual atau kekuatan moral. Ekspresi dari bentuk ketergantungan ini adalah peribadatan dan kewajiban sosial yang harus diemban oleh penganutnya (Scharf, 1995, hal. 30).

Konsepsi beragama dalam konteks individu, merupakan "feeling of absolute dependence" (perasaan seseorang terhadap yang absolut). Agama dalam konteks ini adalah suatu bentuk rasa pengabdian (dedication) atau contentment. Seseorang merasa bahwa ia harus cinta dan mengabdikan diri dengan seluruh kemampuannya kepada agama yang dipeluknya. Bentuk pengabdian ini kemudian tercermin ke dalam pikiran, perkataan, dan tindakan. Dalam konteks inilah agama mampu memenuhi pemeluknya dengan semangat dan perasaan pengabdian diri, sehingga seseorang yang beragama biasanya mempertahankan agamanya secara habis-habisan (Fauzi, 2007, hal. 3). Sedangkan dalam konteks sosial, agama merupakan suatu sistem kepercayaan dan amalan (ritual) yang bersepadu dan berkaitan dengan benda-benda yang sakral, serta dapat menyatukan masyarakat ke dalam suatu komunitas moral (Durkheim, 1995, hal. 44). Persis seperti Ibn Khaldun, bahwa agama merupakan kekuasaan integrasi, kerukunan dan pemersatu, karena agama memiliki semangat yang bisa meredakan berbagai konflik (Farihah, 2014, hal. 188). Jelas bahwa agama dalam kerangka yang positif dapat menggerakkan perubahan sosial ke arah yang lebih baik dan membentuk tatanan masyarakat yang terintegrasi. Sehingga, agama sangat berperan penting dalam memberikan perspektif yang luas untuk memahami aktifitas manusia dan lingkungannya. 
Konsepsi masyarakat beragama menurut Machasin (2011, hal. 7) setidaknya dapat ditandai melalui dua hal, pertama adalah bentuk pengalaman yang bersifat individual dengan Sang Illahi (the holy, the sacred, the dearest), yang melampaui keseharian individu dan bersifat sejati. Agama sebagai sistem nilai, dibentuk melalui proses belajar dan proses sosialisasi. Perangkat sistem nilai ini dipengaruhi oleh keluarga, lingkungan, pendidikan dan masyarakat negara. Selanjutnya berdasar pada seperangkat informasi yang diperolehnya dari hasil belajar dan sosialisasi, kemudian meresap dalam dirinya sebagai salah satu wujud dari perilaku agama yang dipahaminya. Dengan demikian, seseorang dapat dikatakan sebagai umat beragama, apabila di dalam dirinya mempunyai kayakinan terhadap doktrin-doktrin agama, etika hidup, tata nilai, ritual peribadatan, yang kesemuanya dapat menunjukkan ketaatan dan komitmen terhadap agama.

Kedua, adalah bentuk baku dari ungkapan keberagamaan atau lembaga agama. Agama ketika telah membumi, menjadi bagian dari realitas sosial, membentuk identitas pengikut atau penganut yang selanjutnya menjadi kelompok-kelompok sosial. Sejak saat itulah, agama telah "tunduk" pada salah satu fenomena sosiologis menyangkut proses pembentukan identitas kelompok yang melahirkan kelompokkelompok identitas (Abdullah dalam Baowollo (ed), 2010, hal. 98-99). Dari sini memperlihatkan bahwa agama berkembang menjadi sumber penemuan identitas diri (dan kelompok). Kemudian, agama menyatukan orang-orang ke dalam kelompok-kelompok, dan terjadilah pembedaan antar masing-masing kelompok. Pembedaan ini selanjutnya menciptakan dinamika psikologis antara kelompok "kita" dan "mereka". Selanjutnya, untuk meneguhkan identitas kelompok tersebut, dikembangkanlah nararasi besar berupa dasar-dasar keimanan, kisah-kisah dan ritual-ritual keagamaan, keterlibatan dalam upacara keagamaan tertentu dan seterusnya. Narasi ini juga dikuatkan oleh bentuk-bentuk ekspresi keagamaan yang sangat jelas seperti kekhasan pakaian, arsitektur, musik, ritual, dan lainnya. Sehingga, konsep keberagamaan seperti ini tidak jarang akan membentuk solidaritas in group yang mengarah kepada sikap chauvinistik (Ali-Fauzi, 2015, hal. 231-232).

Sedangkan perilaku keberagamaan seseorang dapat dilihat dari beberapa perspektif dimensi, (Fauzi, 2007, hal. 66-68) yaitu; ideologikal, ritual, mistikal, intelektual, dan sosial. Pertama, dimensi ideologis (ideological dimention) atau keyakinan beragama (religious belief). Dimensi ini berkaitan dengan pengakuan dan penerimaan terhadap sesuatu Zat "Realitas Tertinggi" (the ultimate reality), yang sakral, Yang Maha Kuasa, sebagai suatu kebenaran. Kedua, dimensi ritual (ritual involvement), yaitu dimensi yang memberikan keterangan tentang peribadatan dan ritual keagamaan yang harus dijalankan oleh seorang penganut agama. Ketiga, dimensi mistikal atau keterlibatan pengalaman (experimental involvement), yaitu dimensi spiritual-individual berupa perasaan dan persepsi tentang proses kontak dengan The Ultimate Reality (Tuhan). Keempat, dimensi intelektual atau keterlibatan intelektual (intelectual involvement). Dimensi ini menunjukkan tingkat pemahaman seseorang terhadap doktrin dan dogma agama yang dianutnya. Kelima, dimensi sosial atau keterlibatan konsekuensial (consequential involvement). Dimensi ini merupakan manifestasi ajaran agama dan merupakan cermin sikap dalam kehidupan sehari-hari. 
Sementara itu, secara sosiologis fungsi agama terbagi ke dalam lima aspek, (Hendropuspito, 2000); pertama, fungsi edukatif, terkait dengan upaya pemindahan dan pengalihan (transfer) nilai norma keagamaan kepada masyarakat. Fungsi mendasar dan universal peran agama dalam hal ini adalah memberi orientasi dan motivasi serta membantu untuk mengenal dan memahami sesuatu hal yang dianggap "sakral". Kedua, fungsi penyelamat, terkait dengan bentuk-bentuk rasa kedamaian, ketenangan, kasih sayang, dan bimbingan serta pengarahan manusia untuk memperoleh kebahagiaan. Ketiga, fungsi pengawasan sosial (social control), yaitu seluruh pengaruh kekuatan yang menjaga terbinanya pola-pola kelakuan dan kaidah sosial-kemasyarakatan. Dalam hal ini agama memberikan batasan (limitation) dan pengkondisian (conditioning) terhadap tindakan atau perilaku individu atau masyarakat. Keempat, fungsi memupuk persaudaraan (social integratif). Dalam hal ini agama menjadi necessary ingredient of will integrated society (agama menjadi sumber utama terbentuknya integrasi masyarakat yang baik). Agama bahkan dipandang memiliki kemampuan membangun tatanan sosial (social order) yang mapan dan kuat. Agama dituntut adanya identitas dan integritas dalam masyarakat, untuk mengeratkan kohesi dan solidaritas sosial. Kelima, fungsi transformatif dalam perubahan sosial. Dalam hal ini, agama memiliki daya ubah terhadap tatanan kehidupan masyarakat ke arah yang lebih baik. Agama adalah satu keinginan akan suatu cara hidup yang benar dan melakukan pemerataan sosial. Keinginan ini merupakan desakan dari masa kesadaran terhadap kebenaran yang diyakini, sekaligus sebagai tuntutan kesemestaannya (al-Munawar, 2003, hal. 202).

Sementara itu, pembahasan terhadap fenomena atau realitas keagamaan selama ini menunjukkan adanya keruwetan dan kompleksitas konsepsi beragama. Beberapa studi menunjukkan di antaranya kajian yang dilakukan oleh Frederikus Fios (2014) dalam Jurnal Humaniora dengan judul "Tesis, Antitesis, dan Sintesis terhadap Agama”, menjelaskan tentang definisi agama yang menjelaskan bahwa permasalahan terminologi agama memiliki kompleksitas pemaknaan yang didasarkan kepada latar belakang serta ilmu dan paradigma berfikir seorang manusia (Fios, 2014, hal. 73). Secara mendasar, agama dikaitkan dengan hubungan manusia dengan kekuatan transenden yang melampaui daya pikir indrawi manusia. Tulisan ini menyoroti fenomena agama sebagai realitas sosial dengan meneropong isu-isu aktual yang menantang peran agama. Dengan menggunakan analisis hermeneutikkritis, Fios menyimpulkan bahwa peran agama sebagai bagian dari institusi sosial kemanusiaan, merupakan kekuatan yang patut diperhitungkan dalam peta politik dan sosial budaya. Fios mencatat bahwa agama juga bisa menjadi kekuatan yang membelenggu dan menghambat perkembangan peradaban manusia jika para penganutnya tidak menghayati agama secara benar dan bermartabat (Fios, 2014, hal. 80).

Selanjutnya adalah kajian yang dilakukan Wahyudi (2012) dalam Jurnal alFikr yang berjudul "Peranan Agama dalam Perubahan Sosial", menjelaskan bahwa agama merupakan salah satu aspek dalam kehidupan sosial dan bagian dari sistem sosial suatu masyarakat. Agama adalah sebuah kekuatan kolektif dari masyarakat 
yang mengatasi individu-individu dalam sebuah komunitas masyarakat. Seperti, menjawab permasalahan, kebutuhan hidup, serta menghadapi derita, frustasi dan kemalangan. Sehingga menurut Wahyudi, agama diharapkan menjadi sumber motivasi dan kekuatan yang membebaskan individu dari keadaan tertindas dan ketidakberdayaan menuju keadaan yang merdeka (Wahyudi, 2012, hal.186).

Selain itu, kajian yang dilakukan oleh Makmun (2013) dalam Jurnal Religio yang berjudul "Agama di Tengah Jaring-jaring Dunia Modern", menjelaskan bahwa agama harus senantiasa berdialog dengan modernitas dan agama harus bisa dijelaskan dengan bahasa-bahasa yang bisa dipahami oleh manusia modern. Artinya bahwa, menjadikan agama sebagai institusi yang melambangkan cinta kasih. Yaitu, agama yang tidak meletakkan dirinya sebagai pembela Tuhan sambil membantai manusia. oleh karena itu, di era modern agama mampu berperan sebagai katalisator perubahan dan mengontrol kerakusan, keserakahan dan krisis peradaban (Makmun, 2010, hal. 206).

Oleh karena itu, dapat disimpulkan bahwa fenomena keberagamaan atas masyarakat beragama dalam kerangka idealitas, adalah suatu tahapan di mana, masyarakat beragama mampu memahami agama sebagai kerangka sistem nilai dan sistem sosial. Sebagai orientasi kepada transformasi diri yang mengarah kepada perubahan sosial. Karena pada dasarnya, agama akan selalu berkaitan dengan manusia, baik secara individu maupun kelompok masyarakat. Yang secara eksistensial - fitrati — manusia dipandang sebagai "homo religious", menunjukkan bahwa agama merupakan dimensi kebutuhan hidup mendasar (Armstrong, 2002, hal. 20). Faktanya, agama selalu di tempatkan sebagai institusi kultural-sentral oleh masyarakat sepanjang sejarah peradaban manusia. Sehingga, agama berfungsi sebagai suatu sistem nilai dan norma-norma yang mempunyai kekuatan daya ubah (transformabilitas) bagi pemeluk dan komunitasnya (Fauzi, 2007, hal. 61). Jika demikian, ketika agama tidak mampu lagi menunjukkan signifikansi keberadaannya dalam sebuah gerak peradaban yang dinamis, maka agama perlu dipertanyakan keabsahan klaim sebagai pembawa panji-panji keselamatan dan pembebasan umat manusia (Jamil, 2009, hal. 117).

\section{Realitas Masyarakat Beragama; Sebuah Otokritik}

Realitas hari ini, bahwa agama adalah penyebab dari seluruh ketidakmampuan manusia menghadapi kehidupannya. Agama menjadi bentuk wajah suram perdaban manusia modern. Kenyataan ini merupakan bentuk refleksi atas kegagalan peran agama dalam memberikan jawaban terhadap persoalan kemanusiaan yang seringkali terlalu bersifat dogmatis, kurang mencerminkan pemecahan masalah (problem solving) sebagaimana diharapkan oleh masyarakat. Pada akhirnya, agama lambat laun akan semakin ditinggalkan penganutnya, dan beralih ke ideologi lain yang lebih menjanjikan serta mengizinkan tumbuhnya bentuk-bentuk sekularisme baru (Badruzaman, 2009, hal. 119). 
R. Scott Appleby dalam The Ambivalence of the Sacred, Religion, Violence, and Reconciliation (2000), mencatat adanya ambiguitas fungsi agama. Agama, pada satu sisi bisa menghasilkan nilai-nilai humanistis, toleran, inklusif, keadilan, keselamatan, kesejahteraan, cinta kasih, dan perdamaian. Namun di sisi yang lain, agama terlihat arogansi yang membuahkan otoritarianisme, kekerasan, penindasan, konflik, bahkan peperangan, seakan telah melekat pada citra agama. Lahirnya islamofobia adalah bukti konkret dari wajah arogansi agama. Agama seakan-akan mengandung unsur kebencian, sumber konflik, peperangan, bahkan pembantaian atas komunitas lain (the others). Bahkan tidak jarang, agama justru menjadi penghalang bagi kemajuan peradaban umat manusia.

Hal ini diindikasikan akibat model pengajaran agama secara sempit, tidak mendidik, dan memberdayakan, kecuali mengontrol manusia hanya dalam pendekatan halal-haram secara oposisi biner-hitam-putih_adalah salah satu bentuk praktik pendidikan yang menindas. Agama justru membelenggu pikiran dan hati, sehingga cara pandang tidak luas dan tidak terbebaskan karena sistem indoktrinasi. Agama sebagai dambaan manusia ketika mengalami kebuntuan, justru tidak mampu memberikan solusi segar dalam menjawab problem kemanusiaan. Agama disibukkan dengan hal-hal yang eskatologis dan melangit, sehingga jauh dari realitas masyarakat. Kondisi seperti ini akan menyebabkan agama mengalami krisis relevansi (suffering from crisis of relevant) (Badruzaman, 2009, hal. 119).

Realitas semacam ini menimbulkan agama kehilangan peran regulatif dan pembebasan untuk menjawab realitas kebutuhan masyarakat. Padahal, ketika mau menengok dalam konteks sejarah penurunan agama, bahwa para nabi bekerja demi perubahan radikal dalam struktur sosial yang timpang pada masanya. Mereka menggugat kemapanan dari kelompok orang-orang kaya dan penguasa yang menindas. Gagasan dan kritik sosial ini semakin dikuatkan dengan kenyataan bahwa penentang agama-agama pada awalnya bukanlah terletak pada model baru keagamaan berupa penyembahan terhadap Tuhan. Melainkan kekhawatiran mereka terhadap agama tersebut, akan mengganggu dan mengacaukan stabilitas sosial-ekonomi kapital yang mereka bangun. Yaitu akumulasi kekayaan untuk mengekalkan kekuasaan dan praktik penindasan (Engineer, 2009, hal. 52).

Selain itu, agama dalam realitas hari ini justru lebih terlihat sebagai "komoditi seni" yang menjadi tontonan menghibur. Agama terkesan hanya sebuah cerminan kepercayaan individual dengan segala ketentuan penghayatannya. Paling agama diperlukan dalam peringatan-peringatan tertentu yang sifatnya euforia dan seremonial, seperti bulan-bulan suci, pernikahan, dan ritual saat orang meninggal. Fenomena ini menunjukkan bahwa agama mulai kehilangan peran revolusionernya dalam memperbaiki dan menjawab tantangan kemanusiaan. Hal semacam ini akan berakibat pada "pemberhalaan agama" yang menjadikannya sebagai candu sosial (Engineer, 2009, hal. 3).

Agama diciptakan bukan untuk menjadi sebuah "berhala baru", tempat ratapan atas kesengsaraan manusia yang dipuja-puja. Tetapi, sebagaimana disabdakan oleh 
Nabi Muhammad Saw, agama difungsikan sebagai pembina sekaligus penyempurna akhlak dan moral manusia. Berarti memberikan spirit pembebasan terhadap realitas kemanusiaan yang menindas. Arkoun menyayangkan sikap beragama yang berkembang, justru didominasi oleh kecenderungan berfikir (nalar) secara teosentris (al-aqlul aqa'idy). Ciri terpenting nalar ini adalah kecenderungan untuk memusatkan segala persoalan kepada Tuhan, pembahasan problem ketuhanan, dengan merendahkan dan memandang sebelah mata harkat dan martabat manusia beserta problem kemanusiaan (Muhdina, 2010, hal. 20). Menurut Arkoun, kecenderungan ini justru akan membahayakan, karena akan terjadi split dimension antara dunia agama dengan dunia realitas kehidupan manusia. Seolah-olah agama dan realitas hidup manusia, adalah dua entitas yang berbeda dan tidak dapat disatukan. Maka penganut teosentris tak jarang akan mengabaikan problem-problem kemanusiaan.

Demikian Hassan Hanafi, memberikan sorotan terhadap paradigma pemikiran keagamaan yang dianut individu ataupun komunitas tersebut. Menurutnya, paradigma pemikiran dan penghayatan keagamaan yang terlalu teosentris, memiliki anggapan bahwa segala hal yang dikerjakan manusia adalah untuk kepentingan Tuhan semata, dengan mengkesampingkan nilai-nilai kemanusiaan. Mengabdi kepada Tuhan dalam bentuk ritual ibadah dipandang sebagai bentuk peneguhan eksistensi Tuhan, dengan menafikkan realitas kemanusiaan yang mengitarinya (Shimogaki, 2012, hal. 66-67). Akhir dari paradigma pemikiran keagamaan teosentris adalah kenyataan bahwa penganutnya berpotensi untuk "dimabuk Tuhan". Bila "mabuk Tuhan" telah terjadi, tak jarang akan melahirkan tindakan yang tanpa ampun melenyapkan umat manusia demi kepentingan agama dan Tuhannya (Markus dalam Baidhawy, 2009, hal. ix).

Karl Marx pernah mengkritik agama dan menganggapnya sebagai "nafas dari makhluk yang tertindas, hati dari dunia yang tidak berhati, jiwa dari kebekuan yang tak bernyawa, dan candu bagi masyarakat" (Efendi dalam Smith, 2001, hal. x). Harus dipahami bahwa pernyataan ini bukan sepenuhnya menyalahkan agama. Agaknya, Marx menganggap bahwa agama merupakan refleksi dari kenyataan-kenyataan hidup yang terjadi di masyarakat. Agama adalah hasil dari pertentangan kelas sosial. Di mana ajaran tentang surga dan neraka tidak lain adalah refleksi penderitaan dan manuver kaum elit untuk menyembunyikan realitas-realitas tersebut dengan mitos kebahagiaan langit yang abadi. Agama digunakan untuk mempertahankan dan mengabsahkan kedudukan kaum borjuis terhadap kemungkinan kemarahan rakyat atas ketidakadilan yang terjadi. Agama telah menjadi opium, tidak saja karena agama dijadikan sebagai alat penghibur dengan mengumbar janji-janji surga di akhirat sehingga rakyat dapat dininabobokkan, tetapi lebih dari itu, menurut Marx bahwa agama telah mengelabuhi kita dan menyembunyikan kenyataan pahit berupa penderitaan dan kesengsaraan (Tarigan, 2007, hal. 37).

Dalam konteks ini, memberikan gambaran bahwa agama justru menjadi sebuah alat mengabdi kepada penguasa untuk melanggengkan status quo. Bentuk-bentuk komunikasi religius dibangun dalam rangka keuntungan pribadi dan kelompok meski harus mengatasnamakan agama sebagai alat pembenar dan legitimasi bagi 
penguasa-penguasa politik dan kapital yang menindas masyarakat kecil. Agama justru mempecundangi rakyat kecil, meninanbobokan, dan membutakan mereka dari kesadaran diri akan bentuk-bentuk penindasan, diskriminasi, pemiskinan dengan sembunyi di balik topeng agama. Praktik keagamaan seperti ini akan melahirkan apa yang disebut dengan "agama kapital" (Baidhawy, 2009, hal. 69).

Agama sebagaimana dalam QS. Quraisy [106]: 2-4 hadir di tengah-tengah realitas umat manusia sebagai jalan keluar (solusi) dari perasaan lapar dan takut. Agama merupakan salah satu faktor penting penentu kelangsungan hidup manusia. Selain faktor ekonomi, politik, budaya, dan pendidikan, agama menempati posisi strategis dalam melahirkan perubahan sosial (Mulkhan, 2011, hal. 30). Semestinya agama mempunyai perhatian untuk melakukan perlawanan terhadap segala bentuk eksploitasi. Agama dituntut kepekaannya untuk menolak segala hal yang tidak sesuai dengan kemaslahatan dan akal budi. Tetapi justru agama sering lunglai dan tidak rensponsif di hadapan gagahnya realitas sosial.

Sementara itu, realitas sosial masyarakat beragama, sering dihadapkan pada model keberagamaan yang seringkali menempatkan agama hanya menjadi sebuah "paliatif", sehingga membawa para penganutnya untuk menjadi "ashabul kahfi". Yaitu manusia beriman yang takut menghadapi kenyataan hidup dan tuntutan akan pembebasan dari tirani dan penindasan yang terus-menerus. Orang-orang seperti ini yakin bahwa jalan penghambaan kepada Tuhan di hadapan para penguasa dan kapitalis zaman adalah lari dari keramaian, keterlibatan, partisipasi aktif dalam melawan kekejaman mereka, lalu asyik masuk dengan Tuhan mereka, hingga terlelap tanpa tahu bahwa dunia sudah mengalami perubahan (Baidhawy, 2009, hal. 73).

Ciri lain dari model keberagamaan ini ialah, agama mengharu birukan mereka dengan senandung doa-doa dan dzikir yang diiringi sedu sedan tangis dan bah air mata, menghantar ekstase jiwa meratapi dosa-dosa, maksiat-maksiat, kesalahankesalahan, yang selalu menghantui para penikmatnya. Namun, pertobatan via doa dan dzikir itu lebih merupakan alat pembersihan spiritual (spiritual laundry) setelah sekian lama bergelimang dosa. Model keberagamaan semacam ini, adalah bentuk kamuflase dalam realitas semu. Faktanya, pertaubatan itu sama sekali tidak mengubah apa pun atas nasib bangsa ini yang terus terjerembab kemiskinan, pemiskinan, pengangguran, busung lapar, dan rupa-rupa dosa sosial sebagai akibat ketidakpedulian dan hilang kepekaan terhadap fenomena kepapaan dan kefakiran yang jelas membawa kepada kekufuran (Baidhawy, 2015, hal. 55).

Selain itu, menguatnya kesadaran sektarianistik masing-masing penganut agama merupakan satu bentuk kritik sosial bagi masyarakat beragama. Memang tidak dapat dipungkiri bahwa hari ini realitas masyarakat beragama tengah menunjukkan wajah formilnya. Munculnya kesadaran sektarianistik yang semakin menguat cenderung mengedepankan pentingnya agama sebagai "baju" bukan substansinya. Fenomena keberagamaan telah berubah menjadi "lembaga (baca: organisasi)" yang hanya menekankan pada aspek syarat dan rukun formalistik, sehingga harus mencirikan "siapa kita", "siapa mereka" (Abdurrahaman dalam Mulkhan, 2011, hal. 
11). Gejala ini jelas membuat agama seolah-olah telah jatuh dan berubah menjadi ormas dan Tuhan dipanggil di mana-mana sebagai genderang mobilitas masa. Betapa dunia yang sempit—dunia yang menyusut dalam dimensinya. Sebuah dunia tempat suara-Tuhan menjadi terpenjara oleh suara manusia dan suara manusia naik ke singgasana menggantikannya (El-Fadl, 2002, hal. 121).

Sehingga, dalam realitas kehidupan, dengan terjangan deras arus globalisasi dan modernisasi, mempersoalkan tentang hakikat dan fungsi agama dalam masyarakat menjadi sangat penting. Apakah agama dan kaum agamawan—pendeta, pastur, ulama, bikhu, dan sebagainya - mampu menempatkan diri sebagai pembela kaum papa, tertindas dan marjinal dari peminggiran dan pemiskinan sistematis dan struktural globalisasi; atau justru mereka menjadi tameng dan pemberi stempel bagi pusat-pusat kekuasaan kapital yang menciptakan ketidakadilan global? Apakah agama, kaum agamawan dan para penganutnya malah terjerumus ke dalam kapitalisasi agama, cenderung merealisasikan fungsi agama privat yang jauh dari realitas kehidupan, atau tampil di depan melakukan advokasi publik bagi kaum miskin dan tertindas?

\section{Gerakan Menuju Agama Cita}

Konsepsi agama cita, ialah suatu perspektif pemahaman yang berangkat dari kaca mata optimis-positivistik terhadap agama. Pandangan ini melihat agama hadir untuk menyempurnakan tanggung jawab manusia dalam sejarah dan kehidupannya, sebagai sesuatu yang transendetal bagi kebutuhan umat manusia. Perspektif optimis-positivistik selalu merasa bahwa masyarakat beragama selalu dalam naungan dan pelukan agama-agama, tumbuh menjadi manusia kreatif, kritis dan dinamis, mampu melaksanakan tugas peradaban dan kebudayaan untuk mengatur alam serta hubungan antar umat manusia. Agama cita menekankan pada proses dialektika antara idealitas agama dengan realitas masyarakat beragama. Yang mana, agama cita berusaha untuk memadukan dan melakukan sistematisasi terhadap kerangka konseptual agama dan merefleksi realitas agama di masyarakat. Sehingga, akan tercipta paradigma futuristik keagamaan, yang akan menghantarkan kepada sinergisitas agama dan masyarakat beragama untuk senantiasa berdialog secara dinamis dan progresif.

Dalam merumuskan apa yang disebut sebagai agama cita, terlebih dahulu mengimplikasikan kepada tahapan kedewasaan beragama. Artinya, masyarakat beragama harusterlebih dahulu memahami konsepsiagama dan kebutuhan mendasar beragama. Hal ini mengimplikasikan pada aspek kesadaran beragama. Yang pada akhirnya akan melahirkan satu bentuk komitmen dan prinsip bersama untuk mencapai keteraturan sosial. Agama cita setidaknya dapat diukur melalui beberapa hal: pertama, sikap agama bertalian erat dengan solidaritas kemanusiaan. Kedua, sikap religius yang terangkum dalam sikap dan mempersatukan serta mensentralisir nilai-nilai keagamaan dalam satu sintesis pribadi yang khas. Ketiga, sikap religius yang mencerminkan pemikiran kritis, responsif dan kreatif dalam melihat realitas sosial. Hal ini searah dengan tesis Peter L. Berger dalam Durkheim (1995) yang 
menggambarkan agama sebagai kekuatan "world maintaining" dan "world shaking". Artinya, agama dalam kapasitas tertentu mampu mendorong sensitivitas manusia untuk melakukan perubahan sosial. Dengan catatan, pemahaman keagamaan masyarakat telah sampai kepada kedewasaan beragama. Yaitu, agama dipahami sebagai sistem transendental dan sistem sosial.

Sementara untuk mencapai agama cita, terlebih dahulu perlu menghidupkan kembali etos profetik agama-agama besar dunia seperti maksud Islam, sebagai rahmat bagi alam dan seluruh umat manusia (rahmatan lil al-alamin). Konsep ini mengimplikasikan kepada pemeluk Islam dalam praktik keberagamaan yang dilakukan harus bisa memberi manfaat bagi semua orang, Muslim maupun nonMuslim. Sehingga nilai-nilai universal Islam dapat diwujudkan tanpa harus membuat semua manusia memeluk dan mempraktikkan ajaran Islam secara legal-formal (Mulkhan, 2005, hal. 14). Konsep keberagamaan seperti inilah yang lebih relevan dalam konteks masyarakat modern (civil society) dengan kondisi zaman yang serba plural. Sudah tidak memungkinkan lagi untuk berseteru saling adu kebenaran, di saat krisis global sedang mengancam kemanusiaan. Hanya dengan beragama secara inklusif dan humanis akan mampu menghadapi berbagai tantangan modernitas dan krisis global, di mana dalam era saat ini umat beragama dituntut untuk memiliki etos kooperatif sebagai modal dalam menghadapi pentas dunia global. Oleh karena itu, dalam memberikan sumbangsih terhadap krisis relevansi agama, diperlukan gerakan untuk menuju agama cita.

Pertama, gerak langkah menuju agama cita harus terlebih dahulu memberanikan diri untuk saling terbuka dan secara bersama-sama mendeklarasikan nilai-nilai yang universal (Azizy dalam Wasim, dkk, 2005, hal. 3). Kebutuhan akan ruang-ruang diskusi, dialog, dan bertukar pikiran serta kemudian menghasilkan sebuah deklarasi yang universal atas dasar prinsip keagamaan. Proses diskusi dan dialog tidak diorientasikan kepada pencarian titik perbedaan, namun lebih diorientasikan kepada titik temu (common platform). Pada dimensi substansial, agama mengajarkan manusia untuk memiliki nilai-nilai universal. Beberapa hal dalam bentuk nilai-nilai universal yang diajarkan memiliki kesamaan satu sama lain, meskipun masih memiliki doktrin yang berbeda. Jadi, sekalipun doktrin teologis saling berbeda, setiap agama memiliki praktik dan nilai universal, yang dalam hal ini dapat disinergikan. Seperti ajaran tentang kebaikan, keadilan, egaliter, saling menghormati, saling menolong, cinta kasih, dan bentuk-bentuk ajaran sosialkemanusiaan lainnya.

Kedua, penerapan prinsip etika aktivitas misi. Gerakan menuju agama cita harus didukung dengan prinsip-prinsip etik dalam menyebarkan ajaran agama kepada khalayak umum. Karena agama terkadang mempertontonkan perbedaan yang dapat menimbulkan konflik. Setiap agama memiliki ajaran missionaris (baca: dakwah), yaitu setiap organisasi agama masih merasa berkewajiban untuk meningkatkan jumlah pemeluknya dan mengembangkan agamanya dengan mengkonversikan orang-orang dari agama lain (Azizy dalam Wasim, dkk, 2005, hal. 2). Semangat missionaristik setiap agama, pada dasarnya merupakan iktikad luhur 
untuk berbagi anugerah samawi yang diyakini sebagai jalan keselamatan. Masingmasing penganut agama merasa mengemban misi luhur untuk menyampaikan kebenaran kepada orang lain. Hal inilah yang terkadang menyebabkan kisruh dan polemik agama. Sehingga, harus diimbangi oleh penumbuhan sikap toleran kepada orang lain untuk menentukan jalan hidupnya sendiri. Kalau tidak, misi suci tersebut hanya akan mencederai dan merendahkan martabat manusia. Karena, kenyataannya manusia tidak lahir dalam ruang hampa budaya dan agama. Berlangsungnya keberagamaan seseorang lebih banyak lahir dari sebuah proses pewarisan ultimate value dari generasi ke generasi (Efendi dalam Smith, 2001, hal. xii). Prinsip etik aktivitas misi menjadi jalan secara bersama dalam pencapaian harmonisasi umat beragama. Etika aktivitas misi harus memperhatikan sejumlah agenda dalam praktek kampanye dengan menghindarkan diri pada hidden campaign (agenda tersembunyi). Hal ini penting, artinya dalam menjaga kondusifitas arus mobilitas konversi agama. Sehingga dalam ruang ini dibutuhkan dialog yang intensif, karena dialog mengisyaratkan kehidupan yang rukun, termasuk kehidupan dalam mengamalkan ajaran agama.

Ketiga, peningkatan pada skala prioritas pembangunan komitmen antar umat beragama untuk menjaga harmonisasi dan kondusifitas beragama. Gerakan ini dapat dimulai dengan cara membangun sebuah kesepakatan untuk tidak saling bertarung atas dasar agamanya masing-masing. Gerakan ini membutuhkan peranan insan akademis dan para pemikir keagamaan untuk bertugas memberikan penjelasan, pemahaman, dan kesadaran kepada masyarakat beragama tentang sejumlah kredo dan doktrin keagamaan. Gerakan ini berimplikasi kepada spektrum paradigma penilaian standar kebenaran sebuah agama. Artinya bahwa sebuah agama tidak bisa menghakimi kebenaran agama lain menggunakan standar kebenaran agamanya. Hanya penganut agama masing-masinglah yang berhak menilai kebenaran terhadap doktrin keagamaan (Martin, 2002, hal. 2).

Betapa agama, terkadang justru menjadi sekat dan penghalang bagi manusia dalam mengembangkan kehidupannya. Timbulnya kecurigaan terhadap komunitas agama lain menyebabkan masing-masing penganut agama saling menutup diri. Kecenderungan dan kesediaan untuk saling belajar dalam dan dari kalangan berbagai agama, harus menjadi perhatian bersama bagi umat beragama. Sebab, kebangkitan kesadaran beragama bisa saja menimbulkan ketegangan dalam hubungan antar kelompok agama, terlebih dalam suatu masyarakat di mana berbagai agama hidup dan berkembang dalam keadaan berdampingan dan sekaligus bersaing. Sehingga, tidak mengherankan apabila masalah agama dan keberagamaan merupakan masalah "peka". Kemampuan untuk menumbuhkan dan mengembangkan kerukunan hidup antar umat beragama merupakan salah satu tolak ukur kedewasaan dalam beragama (Efendi dalam Smith, 2001, hal. xii).

Keempat, setelah tercapainya kondusifitas dan harmonisasi umat beragama, tahapan selanjutnya ialah kelangsungan akan kebutuhan manusia terhadap agama, mengharuskan terjadinya redefinisi, reformasi, dan reinterpretasi tentang agama dan relevansinya bagi kehidupan manusia. Problem kemanusiaan saat ini seperti, 
kemiskinan, ketidakadilan dan kebodohan, secara nyata semakin menyempurnakan penderitaan, kelaparan dan ketertindasan. Sehingga agama tidak lagi harus berbicara sesuatu hal yang melangit, menjadi euforia bagi umat manusia untuk beranganangan mendapatkan kebahagiaan di akhirat. Markus dalam Baidhawy (2009, hal. vii) menjelaskan bahwa tantangan keberagamaan tidak lagi bersifat doktrinal, melainkan tantangan yang bersifat empirik berupa problem kemanusiaan. Seperti, konflik sosial, kekerasan, ketimpangan, kelaparan, dan ketidakadilan menjadi realitas yang harus dihadapi oleh manusia.

Kelima, agama harus senantiasa memberikan nafas pembebasan terhadap pemeluknya. Agama harus sanggup menterjemahkan dirinya dari bahasa langit, menuju bahasa bumi yang sesuai dengan realitas kehidupan manusia. Agama sebagai institusi dominan dalam diri manusia, harus mampu menjawab tantangan, dinamika dan problematika kehidupan manusia. Ketika manusia dalam keadaan dijajah, ketakutan, kebodohan, ketidakadilan, kemiskinan, pemiskinan, ketimpangan, dan kekerasan. Agama harus sanggup menumbuhkan kesadaran kritis dalam merespon dinamika problem kemanusiaan, baik melalui ijtihad sebagai metode intelektual dalam memahami pesan agama, ataupun secara langsung jika agama diharapkan perannya untuk menyelesaikan problematik masyarakat yang aktual (Engineer, 2009, hal. 48). Artinya agama harus selalu berani memberikan kriteria moral pada setiap keadaan, dengan menunjukan keadaan ideal sesuai dengan nilai-nilai kemanusian. Agama tidak hanya menuntut kepatuhan belaka. Akan tetapi juga pergulatan untuk mewujudkan tatanan yang lebih bertanggungjawab. Melalu perspektif inilah pesanpesan suci agama akan relevan dengan perwujudan keadilan sosial dan ekonomi.

Keenam, terjadinya krisis lingkungan hidup dan kemanusiaan mengharuskan setiap tradisi keagamaan dan komunitas beragama untuk saling berkontribusi dan bekerja sama. Karena pada dasarnya, setiap agama memikul tanggung jawab global. Yaitu tanggung jawab untuk berbuat sesuatu terhadap krisis global dan kemanusiaan. Hal ini harus menjadi landasan bersama, titik berangkat bersama dalam wacana antar iman (Baidhawy, 2002, hal. 200). Spirit agama-agama tidak hanya akan mampu memberi kontribusi untuk mengatasi krisis global, bahkan juga memahami, belajar dari, dan saling memperkaya satu sama lain (Baidhawy, 2002, hal. 201). Oleh karena itu, dalam konteks seperti ini, agama-agama perlu bertemu dan mendiskusikan tentang landasan bersama tanggung jawab global dan tanggung jawab ini harus diatur dan didominasi oleh keragaman agama-agama. Sehingga, akan tercipta keteraturan sosial dalam setiap lintas sektoral, keagamaan dan global.

Pada dasarnya, gerakan menuju agama cita, dalam kerangka ideal akan dapat dicapai ketika masyarakat beragama mampu dan mau menerapakan prinsipprinsip gerak di atas. Sehingga agama tidak lagi dipahami sebagai sesuatu yang ambivalen dan kontraproduktif. Justru agama akan menjadi pegangan terakhir umat manusia dalam menghadapi setiap tantangan perubahan sosial dan terjangan arus modernitas. Kerangka pemahaman inilah yang seharusnya menjadi landasan untuk berpacu gerak dalam adrenalin kehidupan. 


\section{Simpulan}

Kritik dan semangat untuk selalu mempertanyakan fungsi dan peran agamaagama bagi perdamaian harus senantiasa didiskusikan. Seiring dengan tuduhan keterlibatan agama menjadi elemen utama bagi pertentangan yang menimbulkan penghancuran kemanusiaan. Apakah agama bisa menjadi alternatif penyembuhan bagi manusia dari cengkeraman kemiskinan, ketertindasan, ketidakadilan, radikalisme, terorisme, dan peperangan, atau justru hanya akan menjadi bagian pemicu persoalan daripada menyelesaikan berbagai masalah. Berbagai argumentasi di atas memberikan pemahaman kepada masyarakat beragama bahwa agama dalam perjalanannya akan selalu mengalami wajah mendua. Pada satu sisi, secara inheren agama memiliki identitas yang bersifat exclusive, secularist, dan primordial. Akan tetapi, pada waktu yang sama, agama kaya akan identitas yang bersifat inclusive, universalitas, dan transcending. Sehingga, bagaimanapun peran regulasi agama nantinya tergantung sikap masyarakat pemeluknya. Kedewasaan sikap masyarakat beragama akan menentukan wajah agama, apakah akan menjadi sesuatu yang konstruktif atau malah destruktif.

Akhirnya, segala perbedaan dalam konteks beragama, harus dipandang menggunakan kerangka optimis-positivistik, yaitu perbedaan dipahami sebagai sebuah keniscayaan yang dapat menumbuhkan tenggang rasa dan semangat solidaritas antar umat beragama. Beragama membutuhkan sikap dinamis untuk dapat berdialog dengan realitas sosial-kemanusiaan. Menciptakan harmonisasi umat beragama harus dimulai dari sikap keterbukaan diri untuk senantiasa menyesuaikan dengan berbagai realitas sosial-kemasyarakatan. Dinamis dalam beragama berarti menghendaki adanya perbedaan terhadap kepercayaan umat agama lain, dan memandang secara optimis-positivistik. Pastinya, berbagai solusi telah digulirkan untuk diterapkan secara praksis. Agama selamanya akan selalu mengandung cita dan kritik. 


\section{Referensi}

Abdullah, M. A. (1997). Falsafah Kalam di Era Postmodernisme. Yogyakarta: Pustaka Pelajar.

Al Munawar, S. A. H. (2003). Fikih Hubungan Antar Agama. Ciputat: Ciputat Press.

Appleby, R. S. (2000). The Ambivalence of the Sacred; Religion, Violence, and Reconciliation. New York: Rowman \& Littlefield Publishers, Inc.

Armstrong, K. (2001). Sejarah Tuhan; Kisah Pencarian Tuhan yang Dilakukan oleh Orang-Orang Yahudi, Kristen, dan Islam Selama 4.000 Tahun. Bandung: Mizan.

Badruzaman, A. (2009). Dari Teologi Menuju Aksi; Membela yang Lemah, Menggempur Kesenjangan. Yogyakarta: Pustaka Pelajar.

Baidhawy, Z. (2002). Ambivalensi Agama, Konflik dan Kekerasan. Yogyakarta: LESFI.

.(2009). Teologi Neo al-Ma’un; Manifestasi Islam Menghadapi Globalisasi Kemiskinan Abad 21. Jakarta: Civil Islamic Institute.

. (2015). Kemiskinan dan Kritik atas Globalisme Neo-Liberal. Salatiga: LP2M IAIN Salatiga.

Baowollo, R. B., (ed). (2010). Menggugat Tanggung Jawab Agama-agama Abrahamik bagi Perdamaian Dunia. Yogyakarta: Kanisius.

Durkheim, E. (1995). The Elementary Forms of Religious Life. New York: The Free Press A Division of Simon \& Schuster Inc.

Efendi, D. (2001). Agama-Agama Manusia. Jakarta: Yayasan Obor Indonesia.

Engineer, A. A. (2009). Islam dan Teologi Pembebasan. Terj. Agung Prihantoro. Yogyakarta: Pustaka Pelajar.

Fakih, M. (2002). Islam Sebagai Alternatif. Dalam E. Prasetyo, Islam Kiri: Melawan Kapitalisme Modal dari Wacana Menuju Gerakan. Yogyakarta: Insist Press dan Pustaka.

Farihah, I. (2014). Agama Menurut Ibn Khaldun. Fikrah, 2(1), 187-205.

Fauzi, I. A. (2015). Ambiguitas Agama sebagai Peluang dalam Menciptakan Perdamaian Agama. Religio; Jurnal Studi Agama-Agama, 5(2), 223-244.

Fauzi, M. (2007). Agama dan Realitas Sosial; Renungan dan Jalan Menuju Kebahagiaan. Jakarta: PT Rajagrafindo Persada.

Fios, F. (2014). Tesis, Antitesis, dan Sintesis terhadap Agama. Humaniora, 5(1), 71 81. 
Hendropuspito. (2000). Sosiologi Agama. Yogyakarta: Kanisius.

Ismail, F. (2014). Paradigma Kebudayaan Islam; Studi Kritis dan Analisis Historis. Yogyakarta: Suka Press.

Jamil, M. M. (2009). Revitalisasi Islam Kultural; Arus Baru Relasi Agama dan Negara. Semarang: Walisongo Press.

Jauhari, I. B. (2012). Teori Sosial; Proses Islamisasi dalam Sistem Ilmu Pengetahuan. Yogyakarta: Pustaka Pelajar dan STAIN Jember Press.

Kimbal, C. (2008). When Religion Becomes Evil. Canada: HarperCollins Publishers Ltd.

Machasin. (2011). Islam Dinamis Islam Harmonis; Lokalitas, Pluralisme, Terorisme. Yogyakarta: LKiS.

Makmun, R. (2013). Agama di Tengah Jaring-jaring Dunia Modern. Religio; Jurnal Studi Agama-Agama, 3(2), 187-208.

Manzur, I. (1979). Lisanul Arab. Beirut: Dar al-Ma’arif.

Martin, R. C. (2002). Pendekatan Kajian Islam dalam Studi Agama. Terj. Zakiyuddin Baidhawy. Surakarta: Muhammadiyah University Press.

Muhdina, D. (2010). Dekonstruksi Pemikiran Mohammed Arkoun. Al-Fikr, 14(1), 14-26.

Mulkhan, A. M. (2005). Kesalehan Multikultural; Ber-Islam Secara AutentikKontekstual di Aras Peradaban Global. Jakarta: PSAP Muhammadiyah.

(2011). Manusia Al-Quran; Jalan Ketiga Religiousitas di Indonesia. Yogyakarta: Kanisius dan IMPULSE.

Schart, B. R. (1995). Kajian Sosiologi Agama. Yogyakarta: Tiara Wacana.

Shimogaki, K. (2012). Kiri Islam; Antara Modernisme dan Posmodernisme Telaah Kritis Pemikiran Hassan Hanafi. Yogyakarta: LKiS.

Sudarto. (2014). Wacana Islam Progresif. Yogyakarta: IRCiSoD.

Tarigan, A. A. (2007). Islam Mazhab HMI; Tema Besar Nilai Dasar Perjuangan. Ciputat: Kultura.

Wahyudi. (2012). Peranan Agama dalam Perubahan Sosial. Al-Fikr, 16(1), 185202.

Wasim, A. T. (ed). (2005). Harmoni Kehidupan Beragama; Problem, Praktik \& Pendidikan. Yogyakarta: Oasis Publisher. 